(C) 1991 ISIJ

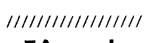

論 文

|IIIIIIIIIIIIIIII

\title{
$\mathrm{A} 533 \mathrm{~B}$ 鋼の延・脆性遷移温度域破壊に おける勒性のばらつきと温度依存性
}

\author{
南雲 道 彦* 井上達 也 ${ }^{* 2}$
}

\section{Temperature Dependence and Scattering of Toughness of A533 B Steels in Ductile-Brittle Transition Region}

Michihiko Nagumo and Tatsuya InOUE

\begin{abstract}
Synopsis :
Temperature dependence and scattering of the critical COD, $\delta_{C}$, and $J$-integral values in the ductilebrittle transition region were investigated with $\mathrm{A} 533 \mathrm{~B}$ steels the microstructures of which were widely varied. $\quad \delta_{C}^{\prime}$ s at the maximum loads were in a linear relation with $J / \sigma_{Y}$ with a proportional constant of 0.49 irrespective to microstructures and test temperatures. It suggests that the stress $\cdot$ strain field at the crack front area could be described with the Hutchinson, Rice-Rosengren solutions even at the D-B transition region.

Linear relations also existed between $\delta_{C}$ as well as $J$ and the stretch zone width, $s z w$, but the data were grouped according to the relative locations of the test temperatures in the transition region. Analysis in terms of tearing modulus was also examined, suggesting that the resistance to the crack extension is temperature and microstructure dependent. It was discussed that the temperature dependence of the toughness and its scattering at a given test temperature could be discriminated in a sense that the former is related to the resistance of the crack extension while the latter is to the transition to the stable crack or brittle crack initiation.

Key words : toughness; COD ; $J$-integral ; ductile-brittle transition; A533 B steel; fracture ; fracture mechanics ; scatter of toughness ; tearing modulus.
\end{abstract}

\section{1. 緒}

鉄鋼は一般に延・脆性遷移温度域が広く，実用的な靬 性も遷移温度域で指起されることが多い。遷移温度域で は不安定脆性破壊に先立って塑性変形が大きく，予き裂 の鈍化や安定き裂の発生・成長が起こる。靸性值にはこ のき裂先端の塑性変形から不安定破壞にいたる過程が本 質的に重要である。遷移域の勒性を温度依㐿性の観点か ら考察する場合には降伏心力の温度依存性に代表され $る^{1)}$ 材料の本来の塑性変形挙動が問題になる。一方, 遷 移域の勒性は一般にばらつきが大きい。これには材料の 不均一性が原因であると考えられ，材料としては異常值 的な見方がされることが多い。ある試験温度での靱性值 が材料の本来のものか買常值であるのかを区別すること は材料の設計及び使用に対して重要なことである.

従来の破壊理論ではき裂先端の心力状態が重視され,
局所的にへき開破壞強度を超えることが破壞条件とされ ることが多い2．き裂先端に塑性変形が㓐起された場命， その役割の一つは塑性拘束による心力状態の変化であ る3)。しかし，き裂先端の鈍化が大きく，とくに安定き 裂の発生がある場合は，き裂先端での心忍力状態だけでは なく，延性破壊的な要素に注目する必要がある。この場 合には変形のミク口的な状態が重要であり，また特に材 料の不均一性は変形の不均一さをとおして脆性破壞たけ でなく延性破壞過程においても作用する川能性がある. 塑性変形はき裂先端からせん断変形带として局所的に進 行し，全域降伏において塑性ヒンジとして発達する4). き裂先端の塑性变形が小規模降伏にとどまっていると きのき裂先端近傍の忍力・歪み場は加1硬化材料につ いて $J$ 積分を用いた Hutchinson, Rice-Rosengrenの解 $(\mathrm{HRR} \text { 解 })^{5) 6)}$ で与えられるが，遷移温度域では塑性㤎 形は全域降伏を超えておこり得る。したがって遷移温度

平成 2 年 9 月日本金属学丟にて一部発表 平成 2 年 9 月 12 H受付 (Received Sep. 12, 1990)

* 早稲田大学各務勆念材料技術研究所 理博 (Kagami Memorial Laboratory for Materials Science and Technology, Waseda University, 2-8-26 Nishiwaseda Shinjuku-ku, Tokyo 169)

*2 早稻田大学大学院 (現: 住友電気 Ltd.) 
域全体にわたる鞀性の構度依存性やばらつきについて も，それぞれの值が破壞条件としてどう表現されるかを 調べることはそれぞれの破壊の支配機構の違いがもしあ るとすればその解明の上に有用であろう.

HRR 解は小規模降伏の状態を前提にして導かれたも のであり, 変形が進行してき裂先端の形状変化が起こる とその成立する領域は限定されてくる，塑性域が拡大し たときの応力・歪み場はすべり線場による解 ${ }^{778)}$ や有限 要素法による解 ${ }^{3) 9}$ が求められているが, HRR 解も近 似的にあてはまることが示され7), き裂開口変位と $J / \sigma_{Y}$ $\left(\sigma_{Y}\right.$ : 降伏強度 $)$ との関係が求められている ${ }^{9)}$. したがっ て, き裂先端近傍の応力・歪み場と鞉性の温度依存性や ばらつきとの関係を調べるには開口変位と $J / \sigma_{Y}$ との関 倸が一つの手掛かりになる。これは遷移温度域での破壊 条件の表現とそれを決めている因子を抽出する一つの手 法となろう。また塑性変形が進行したときのき裂先端の 形状変化は応力・歪み場に影響を与えるものであるが, 理論的な予測は困難であり，実験的な観察が必要である。 これらの観点での研究は少ない.

本研究では $\mathrm{A} 533 \mathrm{~B} \mathrm{cl} 3$ 鋼の組織を大幅に変えた材料 を試料として, 遷移温度域での䩲性のばらつきと温度依 存性が区別されるかどうか，また材質の違いが鞀性に影 響する機構を解明することを目的として行った。

\section{2. 実 験 方 法}

供試材は A533 B cl3 鋼で Table 1 に成分を示した。 原厚 $150 \mathrm{~mm}$ の極厚材で熱処理されたものから表層部と 中心層を除いた $60 \mathrm{~mm}$ の部分から压延方向に直角を $L$, 板厚方向を $B$ とした $22(W) \times 105(L) \times 120 \mathrm{~mm}(B)$
の板を切り出し， 3 種の熱処理を施した。熱処理条件は オーステナイト粒径を二と抢りに变えた焼もどしマルテ ンサイトとフェライト・マルテンサイト混合組織との 3 種となるように選んだ。熱処理条件と常温で測定した硬 さを Table 2 に，また光学顕微鏡組織をPhoto. 1 に示 した。硬度測定は荷重 $500 \mathrm{~g}$ のミクロビッカース硬度計 を用いた。靱性試験はBS5769に準拠した COD 試験と, ASTM E813-86 に準拠した J J 試験を行った。試験片 の予き裂は疲労き裂にするのが一般的であるが，今回の 試料では $0.15 \mathrm{~mm}$ 幅のスリットを切削によって導入し た。これはおのおのの試験片の予き裂形状をできるだけ 同じようにするためと，今回の研究では比較的鞎性の人 きい温度領域が対象になるため，予き裂の先端の鈍化が 大きいことが予想されたからである。

3 点曲げ試験は $0.5 \mathrm{~mm} / \mathrm{min}$ の一定のクロスヘッド速 さで行い，クリップゲージ出力を荷重に対して記録する とともに, 荷重の時間変化を記録して荷重-荷重点変位

Table 1. Chemical compositions of the material ( wt \%).

\begin{tabular}{ccccccc}
\hline $\mathrm{C}$ & $\mathrm{Si}$ & $\mathrm{Mn}$ & $\mathrm{P}$ & $\mathrm{S}$ & $\mathrm{Mo}$ & $\mathrm{Ni}$ \\
\hline 0.19 & 0.28 & 1.50 & 0.009 & 0.006 & 0.53 & 0.65 \\
\hline
\end{tabular}

Table 2. Heat treatment conditions and hardness of tested materials.

\begin{tabular}{c|c|c|c|c}
\hline Series & Quenching & Tempering & DPN & $\sigma_{Y}(293 \mathrm{~K})(\mathrm{MPa})$ \\
\hline $\mathrm{A}$ & $1173 \mathrm{~K} \times 1 \mathrm{~h} \rightarrow$ O. Q. & & 263 & 650 \\
\hline \multirow{2}{*}{$\mathrm{B}$} & $1053 \mathrm{~K} \times 1 \mathrm{~h} \rightarrow$ O. Q. & \multirow{3}{*}{$823 \mathrm{~K} \times 2 \mathrm{~h} \rightarrow$ O. Q. } & 244 & 612 \\
\cline { 1 - 1 } \cline { 5 - 5 } $\mathrm{C}$ & $1473 \mathrm{~K} \times 1 \mathrm{~h} \rightarrow$ O. Q. & & 265 & 650 \\
\hline
\end{tabular}
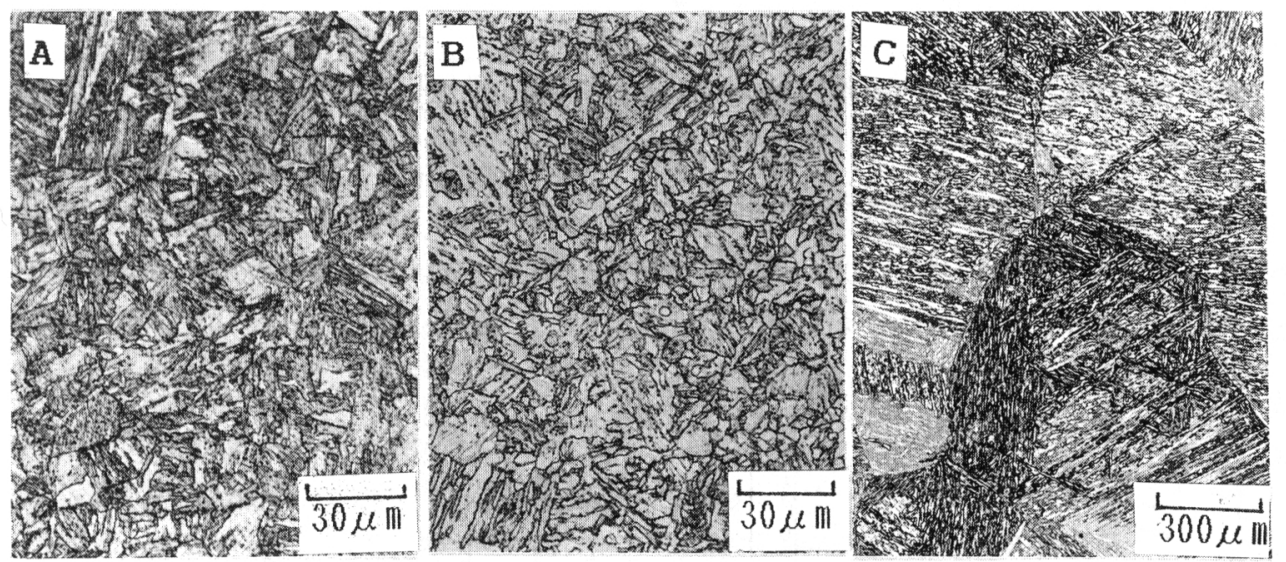

Photo. 1. Optical micrographs of the materials. Each photo corresponds to specimen series in Table 2. 
曲線を得た。限界 COD 值 $\delta_{C}$ は最大荷重点における開

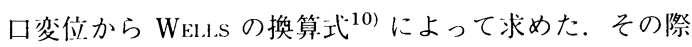
必要になる試験温度に打ける降伏強さ $\sigma_{Y}(T)$ として は, 公温での硬さの測足傎から至温の降伏強さ $\sigma_{Y}(294)$ に換算した。換算はビッカース硬さから引張強さを

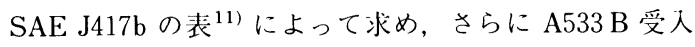
材の降伏比の実測值 0.78 から降伏強さを求めた。また さらに温度依你性は次式 ${ }^{12)}$,

$$
\sigma_{Y}(T)=\sigma_{Y}(293) \exp \left\{\left(389.5-80.5 \times \ln \sigma_{Y}(293)\right) /\right.
$$

$$
(1 / T-1 / 293)\}
$$

から推分した値を用いた。

また $J$ 積分值は荷重-荷重点变位曲線から試験片にな された仕事に相当する面積 $A$ をプラニメーターで測走 し，実際の什事量に換算した後で RicE の式 ${ }^{-13)}$,

$$
J=\frac{A}{B(W-a)} \cdot f(a / W)
$$

から求めた。ここで $f(a / W)$ は試料形状から 2.0 とし た.

今回の実験では最人荷重にいたるまでに破壊した試験 片と, 最大荷重点を超えてから破壞した試験片との二つ のタイプがあった：そこで最大荷重を超えてから破壊し た試験片については最大荷重点までの仕事量から求まる $J$ 積分値を $J_{1}$, 試験片が破断するまでの仕事量から求 まる $J$ 積分値を $J_{2}$ とした。

試験温度は $-196^{\circ} \mathrm{C}$ から $-20^{\circ} \mathrm{C}$ の範用とし, 約 $20^{\circ} \mathrm{C}$ おきに試験を行って遷移曲線を得るとともに, 遷 移域の低温側の 1 温度と, それから $30^{\circ} \mathrm{C}$ 高い温度のそ れぞれで各 10 本の試験を行ってばらつきを求めた， A, $\mathrm{B}$ 系列では $-120^{\circ} \mathrm{C}$ と $-150^{\circ} \mathrm{C}, \mathrm{C}$ 系列では $-90^{\circ} \mathrm{C}$ とー $120^{\circ} \mathrm{C}$ である.

破断した試料は予き裂先端の形状及び破面形態を走査 型電子顕微鏡で観祭し，ストレッチゾーン長さ $(s z w)$, 安定き裂長さ $(\Delta a)$, 脆性破壊発生点距離 $(X)$ などを
測定した。ストレッチゾーン長さは場所によって不規則 であるので, 脆性破壊発生起点の值上で予き裂の底に 沿って $1 \mathrm{~mm}$ の幅をとり，その下のストレッチゾーンの 面積を測定してそれから平均的な長さを求めた，従って もとの予き裂の先端が開口するとともに前進した距離を 測走していることになる。また脆性破壊発生起点距離は ストレッチゾーン，また安走き裂がある場命はその先端 からの值である.

\section{3. 実 験 結 果}

靶性の遷移挙動として限界 COD $\delta_{C}$ の温度依存性を Fig. 1 に示した。遷移域中の 2 温度での各 10 本の試騃 のばらつきを同時に示してある．刚に見られるように広 い温度範囲で鞀性が変化し，1温度でのばらつきも大き い.ばらつきを調べた 2 温度での試験で， $\delta_{C}$ と最大荷 重点での $J_{1}$ 值との関係を Fig. 2 に示した。試料の表

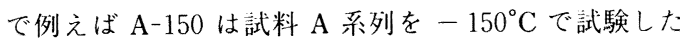
ことを表す．汹で $J_{1}$ は各試料の降伏強さとの比でとっ てある、刚にみられるように直線的な関係があり，

$$
\delta_{C}=\lambda \cdot J_{1} / \sigma_{Y}
$$

で表して回帰分析で求めた各試料系列の $\lambda$ table 3 に示した.試料ごとに差があるが系統的なものではなく， 0.5 付近の值である. 全試料を原点をと扔る一本の直 線で近似すれば試料の熱処理条件や試験温度によらず, $\lambda=0.49$ でほぼ一義的に表される.

COD はき裂先端の鈍化現象であるが，ストレッチ ゾーンの形成はしばしば予き裂先端の前進を伴う. $\mathrm{COD}$ と szw との関係は一義的に定まるものではなく,

Table 3. Proportional constant $\lambda$ of equation 3 of each series by regression analysis.

\begin{tabular}{c|ccccccc}
\hline Series & A-120 & A-150 & B-120 & B-150 & C-90 & C-120 & Total \\
\hline$\lambda$ & 0.471 & 0.437 & 0.529 & 0.337 & 0.508 & 0.477 & 0.494 \\
\hline
\end{tabular}

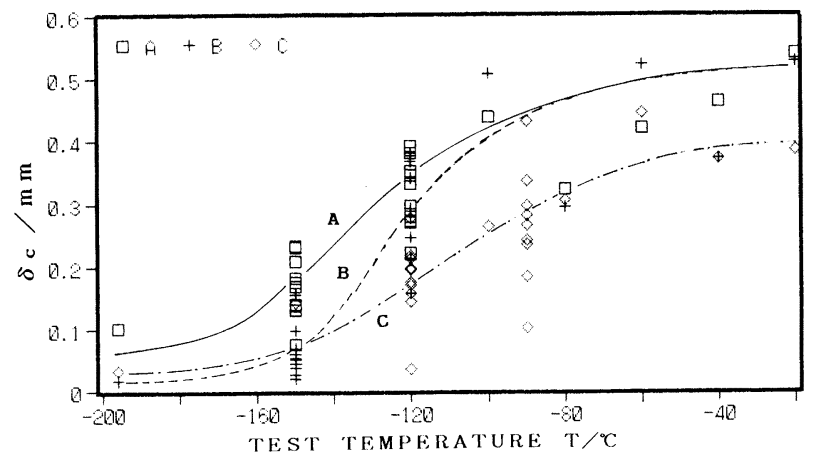

Fig. 1. Temperature dependence of critical COD, $\delta_{C}$. 

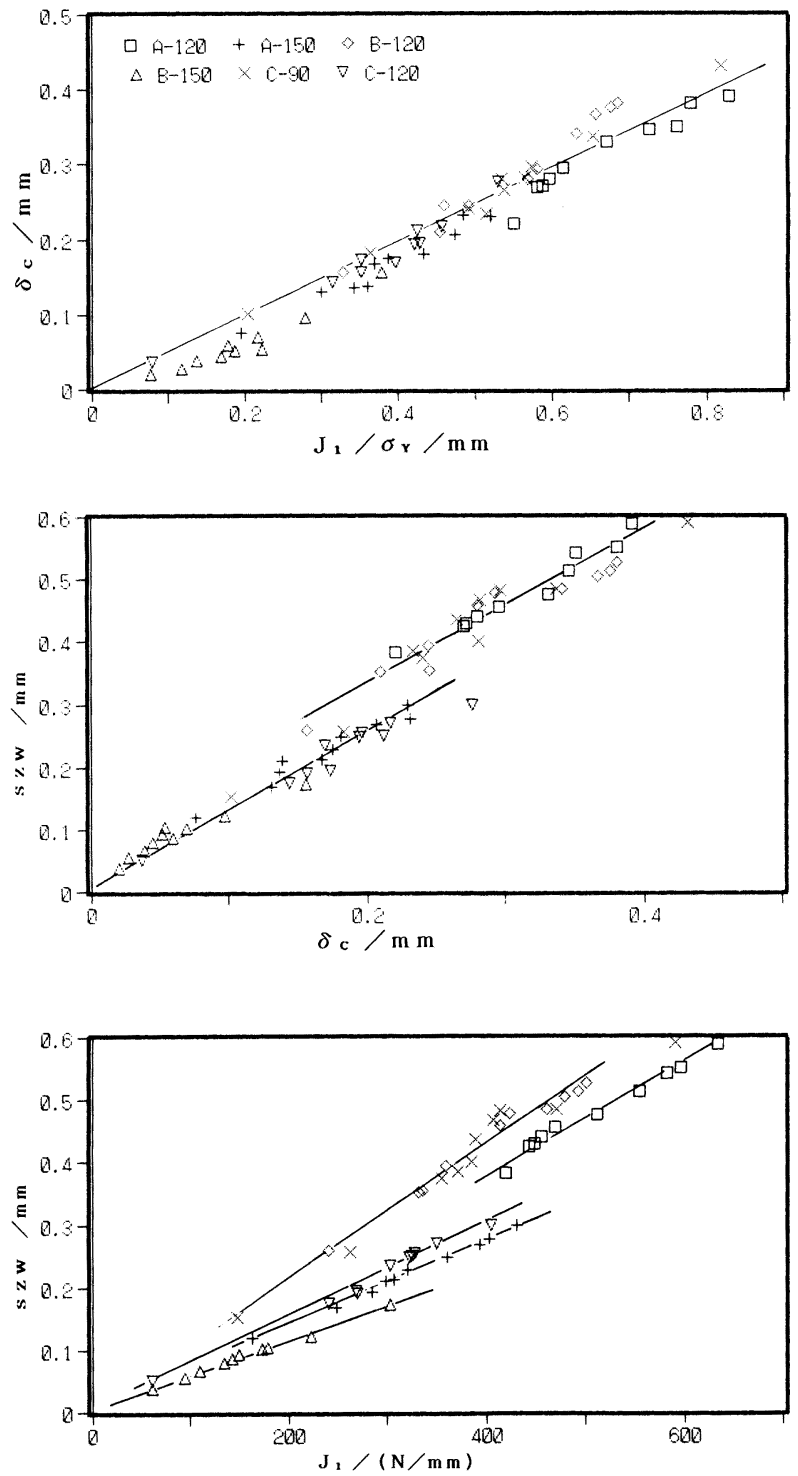

Fig. 2. Linear relationship between $J_{1} /$ $\sigma_{Y}$ and critical $\mathrm{COD}, \delta_{C}$ of specimens which show scattered values at two test temperatures. Symbols are indicated in the figure. A-150, for example, indicates specimens of series A tested at $-150^{\circ} \mathrm{C}$.

Fig. 3. Relationship between the stretch zone width, szw, and critical COD, $\delta_{C}$ showing separate groups corresponding to relative test temperatures. Same symbols as Fig. 2.
Fig. 4. Relationship between the stretch zone width, szw, and $J$ values at maximum load. Same symbols as Fig. 2.
き裂先端の形状についての情報を与えることになる.

Fig. 3 は COD と szw との関係であるが, 注目されるこ とは，両者に直線的な関係があるとともに，遷移域の低 温側とそれより高温側とで二つのグループに分かれるこ とである。この事実は靱性の温度依存性と同一試験温度 でのばらつきとが区別されること，そして遷移域内での 相対温度によってき裂先端の開口がき裂の前進を伴う程 度が異なることを意味する。

き裂の前進量として $s z w$ をとり，J $J_{1}$ との関係を見た のが Fig. 4 で，これはストレッチゾーンの進展に必要 な外部から供給する歪みエネルギーを表す一種の $R$ 曲
線である. szwと $J_{1}$ には比例関係があるが勾配は各試 料によって異なる．また注意深くみると遷移域内の相対 温度によって二つのグループに分かれる傾向が認められ る.

今回ばらつきを調べた試料では，破面上に安定延性き 裂が認められたのは遷移域の高温側の少数の試料のみ で，大部分の試料はストレッチゾーンから直接に脆性破 壊に移行していた。試料が最終破断するまでの荷重一荷 重点変位曲線の面積から求めた $J_{2}$ 值とき裂進展量とし ては $s z w$ と安定き裂長さとの和をとってプロットした 結果が Fig. 5 である. $J_{2}$ として，安定き裂がない場合 

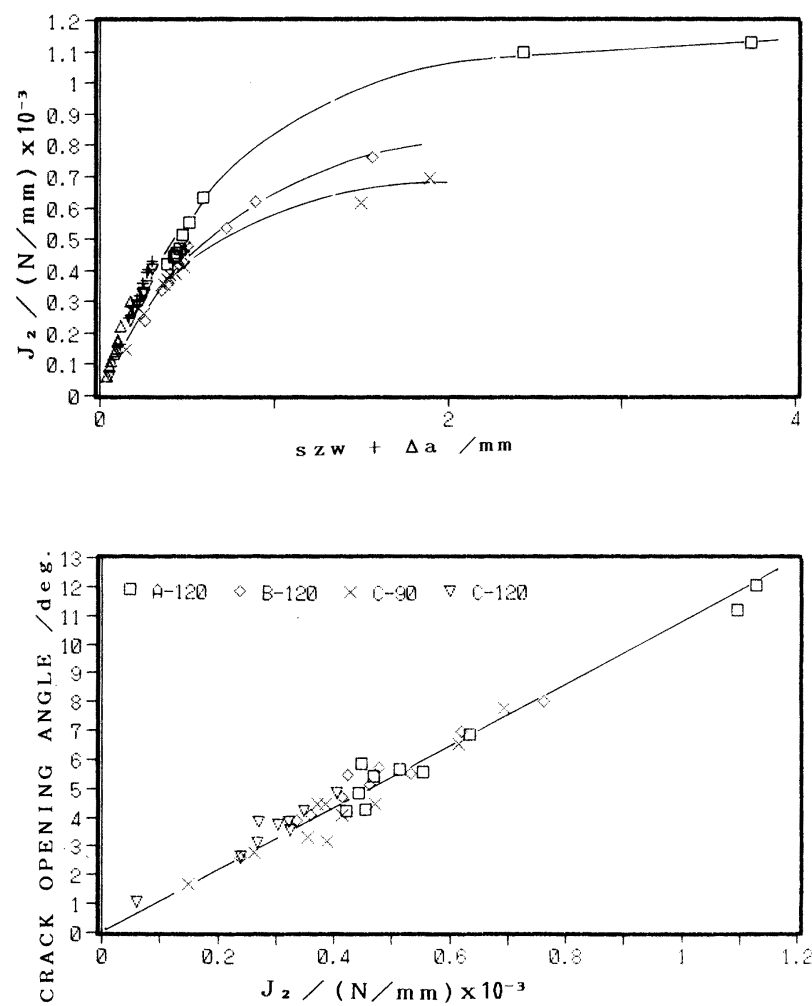

Fig. 5. Relationship between $J$ values at the final fracture and the crack extension length, szw $+\Delta a$, where $\Delta a$ is the stable crack length. Same symbols as Fig. 2.

Fig. 6. Linear relationship between $J$ values at the final fracture and bend angles of specimens.

は $J_{1}$ 值をとった．Fig. 5 は安定き裂の進展における伝 播抵抗を表す $R$ 曲線である. 測定点が少ないことと, 安定き裂の形が一様でないために $J_{2}$ 值の意味に曖昧さ があるので断定は慎重であるべきであるが，安定き裂の 伝播において試料の差が顕著になる。

次に, $J_{2}$ 值と試験片のマクロ変形量との関係を調べ た。マクロ変形量としては破断した試験片の幅が破断部 で増加している最大幅から求めた横拡張率 $\Delta l$ と, 試験 片の破断時の曲がり角（き裂開口角）をとった. $\Delta l$ と 曲がり角とは比例関係にあることが確認されたのでどち らをとってもよい， $J_{2}$ と曲がり角との関係を Fig. 6 に 示した. 試料の熱処理や試験温度によらず，一義的な対 忍がある，靱性とマク口変形量との一義的な対忍は，著 者らがさきに見出したシャルピー試験の吸収エネルギー と試料の横拡張率との関係 ${ }^{14)}$ に類似である.

今回の試料の破面形態はストレッチゾーンが形成さ れ, 安定延性き裂の発生, 脆性破壊へ移行するという点 では其通的であるが，ストレッチゾーンや安走き裂の分 布状態は不規則であった。安定き裂は予き裂の底で一様 にではなく，敌状に生ずる，またオーステナイト粒径の 大きな $\mathrm{C}$ 系列試料で脆性破面の山凸が顕著であった。
脆性破壊発生起点も必ずしも一つではない，起点距離と $J_{2}$ 值との関係を Fig. 7 に示したが，一定の関係を見出 すことはできなかった。

\section{4. 考察}

線形破壊力学が成立する場命には式( 1 ) の入は 1 で

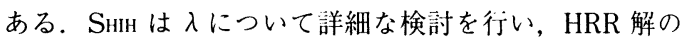
成立する範囲では $\lambda$ は加工硬化指数 $n$ と $E / \sigma_{Y}$ の関数 であることを示した ${ }^{9)}$. 入に影響を与える因子としては， ほかに平面心力ゃ平面歪みなどの忍力状態がある ${ }^{15)}$.

今回の結果では $\lambda$ は試料の熱処理条件や試験温度に よらず，ばらつく靱性值に対して一義的に 0.49 であっ た. RICE らの計算では $n<0.2$ の場合に 0.58 であり ${ }^{6)}$, また A533 B 鋼について 0.55 という值が報告されてい $\tau^{16)}$ ，今回の結果はこれらとほほ一致する．今回の試 料では $n$ は大きく変化することはないとみなされ，試 料のミクロ組織，鞀性のばらつきをおこす原因，あるい は試験温度は入にたいする支配因子としては関与して いないことを意味する。言い換えれば，遷移域でも最人 荷重点でとった $\delta_{C} や J_{1}$ 值に大きなばらつきがあって も，忍力・歪み場は HRR 解で近似できることを意味し 

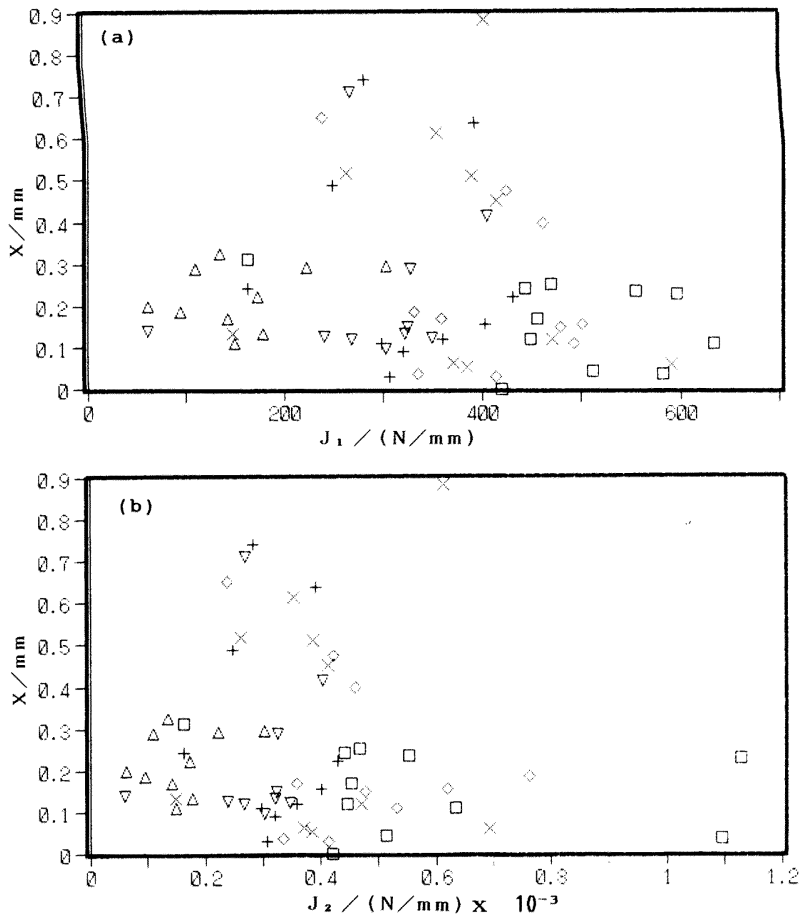

Fig. 7. Distance $X$ to the brittle crack starting points from the crack front related to $J$ values at (a) the maximum load and (b) the final fracture. Same symbols as Fig. 2.
ている.

一方，ストレッチゾーンの形成は単にき裂先端の開口 だけではなくき裂の前進を伴う。ここで求めた $s z w は$ 予き裂の進展量でもある。この場命開口変位はき裂先端 の位㯰が動かなくとも起こり得るから， $\delta_{C}$ と $s z w$ との 比,すなわちき裂開口角は一義的に定まるものではなく， 做々の試料の破壊過程をあらわす量としてとりあげるこ とができる. Fig. 3 は $\delta_{C}$ と szw とが㨁線関係にあるが 遷移域での相対温度によって二つのグループに分かれる という結果で,これは, 高温側ではき裂の前進がおこり やすいことを意味する．今回の実験では予き裂として機 械ノッチを用いたので脆性域では勒性を大きく評価する 叮能性がある。しかし今回検討の対象となった靶性範囲 では塑性変形が火きく，また同一のszwに対しても試 験温度によってグループ分けされることから, Fig. 3 の 結果は予き裂形状によらない本質的な現象であると考え られる。

Fig. 2 と Fig. 3 の結果は靸性の温度依存性とばらつ きとを区別する点で重要である. Fig. 4 の J 值と szw との関係はき裂の鈍化段階でき裂の前進に対する抵抗を 表し, 今回の各熱処理試料はそれぞれ異なる伝播抵抗を 持つことになる．各試料の靶性が試料系列ごとに一つの 淔線で整理されることは靶性にばらつきがあっても伝播
抵抗は試料のミクロ組織で決まり，一ナばらつきはき裂 先端の鈍化過程で安定き裂あるいは脆性破壊へ移行する 点を変えるものである．また遷移域内の相対温度によっ て大別され，高温側ではき裂の鈍化の古期に前進がおこ ることを示している．まだ裂の伝播抵抗に対する試料 の差は安定き裂の成長においていっそう顕著である。き 裂の伀播抵抗をPARIS が定義したティアリングモディラ ス $T_{R}$,

$$
T_{R}=\frac{E}{\sigma_{Y}^{2}} \frac{d J}{d a}
$$

で表せば17)，ヤング率 $\mathrm{E}$ は今回の試料では一定とみな してよいから， $J_{1} / \sigma_{Y}{ }^{2}$ と szw との関係は Fig. 8 に，ま た最終破断時の $J_{2} / \sigma_{Y}^{2}$ とき裂長さとの関係は Fig. 9 で 示される. Fig. 8 で注目されることは，遷移域の低温側 と高温側とで勾配が異なることである，すなわち，き裂 の鈍化段階では $T_{R}$ が遷移域内の相対温度によって異な る值を持ち, 高温側では伀播抵抗が小さくなることが見 出された。また，同一試験温度で勒性のばらつきを示す 試料は同じ組織であれば $T_{R}$ としては変わらない。一方 Fig. 9 から安䇥き裂は遷移域内の高温側でしか見出され なかったが, $T_{R}$ は試料のミクロ組織依存性を持つよう である。

曲げ変形でき裂先端の塑性変形に伴ってき裂が前進す 

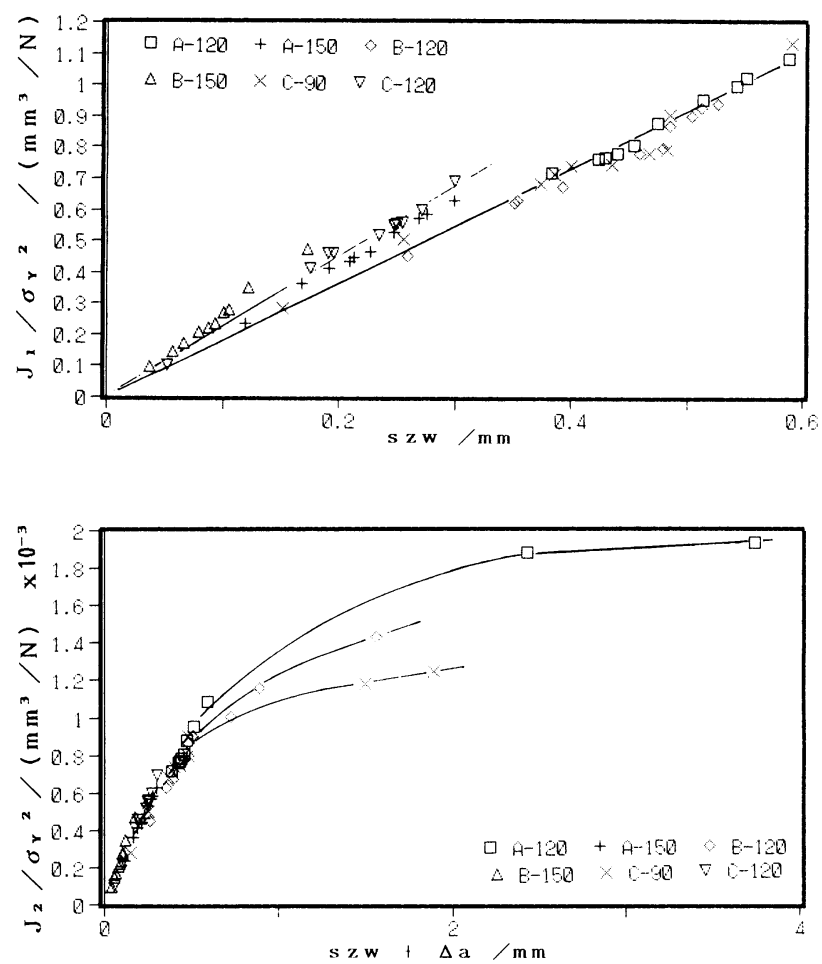

Fig. 8. $J_{1} / \sigma_{Y}^{2}$ plotted against the stretch zone width, i. e. $R$ curve of the stretch zone extension.
Fig. 9. $J_{2} / \sigma_{Y}{ }^{2}$ plotted against the crack length, i. e. $R$ curve of the stable crack extension, szw $+\Delta a$.
るには二つの過程が含まれる，すなわちき裂先端でせん 断带が発生することによるき裂先端の変形に伴うス卜 レッチゾーンの形成と, 安定き裂の生成・成長における 延性破壊プロセスである.

き裂伝播に要するエネルギーは破壊までのマクロな変 形量と変形忍力との積であり，き裂の伝播抵抗に対して 屾者の奇与を分離することは困難である。しかし加に硬 化指数は今回の試料ではほとんど変わらないと考えら れ，また今回の $30^{\circ} \mathrm{C}$ 程度の温度差では変形抵抗の変化 も著しくはない。このような条作下で靶性に差が生ずる ことは試料内の変形域の分布とき裂先端領域での限界変 形量に主な原因があり，ここに遷移域の特微が存在する ように思われる。

この点で，今回の結果でき裂の伝播抵抗が試験温度の 絶対值ではなく，遷移域内の相対温度で分類されたこと は注目されることである。これはさらに広範囲な実験で 確かめる必要があるが，遷移温度域の広がりの本質に関 する叮能性がある．遷移現象の素朴な概念は降伏強さと へき開強さとの大小関係の和転であるが，不安定破壊に 先立つ塑性变形が大きい場介には靶性には塑性変形量が 主要な役割を持つ。とくに鉄鋼のような不均一な組織の 材料の場命には, 塑性変形の広がりとその中での歪み分
布が温度によって敏感に変化するであろうし，これらの 破壊条件への関与が遷移温度域を形成する川能性があ る.

個々の試料の䩚性のばらつきは，変形の過程で安定き 裂あるいは脆性破壊に移行する限界条俳への到達が恭な

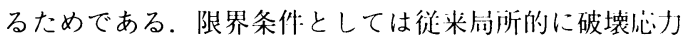
への到達がクライテリアとしてあげられていることが多 い. 従来, $K_{\mathrm{IC}}$ と脆性破壊発生起难距離との相関が見出 されている例は多い17)18)。トリガー点がき裂先端の忘 力場の中に取り込まれることによって脆性破壊へ移行 し，その時の心力が鞀性值を決定するとすれば必然的に 理解されることである.

今回の場今は，最大荷重点及び最終破断時のいずれに おいても $J$ 值と脆性破壊起点との間には規則的な関倸 が見出されなかった、ストレッチゾーンの形成，安定き 裂の発生・成長では塑性変形量が大きく，また延性破壊 的な過程であるから，遷移域では鞁性に対してこれらの 奇与が大きく，トリガー点が塑性域の中にとりこまれる ことが決定的な条件ではないことを意味する，いいかえ れば，トリガー点が存在していてもそれが活性化するま での過程が靱性を決走することになるであろう。トリ ガー点の存在位置よりもその活性化過程におけるばらつ 
きが靶性のばらつきの原因であると考えられる。これに 对しては塑性域内での店範囲な变形状態と局所的な限界 変形能への到達が重要な観点であろう.

破断時までの変形に要したエネルギー $J_{2}$ 值が試料の マクロ変形量であるき裂開口角 $C O A$ や横拡張率と一義 的に対忍することが見出されたが，シャルピー試験での 結果 ${ }^{13)}$ とあせて、これは遷移域破壊の一般的な現象 のようである。き裂先端の局所化した領域だけを考えれ ば，歪みエネルギーは当然降伏強さに依存するはずで, 间一・szwにたいして $J_{1}$ が降伏強さによって変化するこ とを示す Fig. 4 にみられると抢りである。一方，変形 が進行した時の $J_{2}$ 值には試料全体にわたる変形が寄与 するであろう。遷移温度域で脆性破壞への移行において は，き裂先端領域における破壊条件への到達に、試料全 体の変形が関与していることを示唆している.

\section{5. 結 論}

組織を大幅に変えた A533 B 鋼を用いて延性・脆性遷 移温度域で限界 COD 值及び $J$ 積分值の温度依存性とば らつきとを調べた. 主要实験絬果は以下のとおりである。

1)ばらつきを調べた 2 試験温度に抢いて，限界 COD 值とそこでの $J$ 積分值との間には，き裂先端領域 での忍力・歪み場を記述する HRR 解から予測される,

$$
\delta_{C}=\lambda J_{1} / \sigma_{Y}
$$

が成立し，試料の組織や試験温度によらずほぼ $\lambda=$ 0.49 であった。

2 ) COD 值とストレッチゾーン長さとの間には㨁線 的な関係があり，遷移域の低温側と高温側とで異なるグ ループに分かれた。

3 ) $J_{1}$ 值とストレッチゾーンとの関係も同様である が, 試料の組織の影響が認められた。最終破断時までの $J$ 值とき裂進展量との関係を表す $R$ 曲線において, 㚣 盗き裂の成長に試料の組織の影響が大きかった。

4 )破断までの試験片のマクロ変形量と $J$ 值とは, 試 料の組織や試験温度によらず一義的な対忍がある。

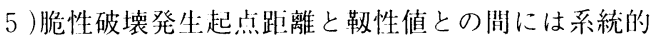
な関係は認められなかった。

これらの結果から以下のような結論が導かれた。

a 塑性変形の大きな遷移温度域においてもき裂先端 領域の忍力・歪み場は HRR 解で近似できる。

b )鞁性の温度依你性とばらつきとは次の点で区別で きる。すなわち温度依存性はき裂の伝播抵抗と関連し, 高温側でき裂鈍化の早期に前進が㧍きる。これは試験温
度の絶対值ではなく，遷移域内での相対温度できまるよ うである。一方，ばらつきはき裂先端の鈍化過程で安定 き裂あるいは脆性破壊への移行点に関係する.

c )ティアリングモデュラスでき裂の伝播抵抗を表せ ば高温側で小さい。またテイアリングモデュラスは靱性 のばらつきには関係しないが組織依存性は持つようであ 万.

d ) 遷移域で脆性破壊への移行にはトリガー点の位置 よりもトリガー点を活性化する過程が支配する。これに はミクロ的な塑性変形の不均一性が関与すると考えられ る.

本研究は日本鉄鋼協会平成元年度特定基礎研究単独依 頼研究資金で行われたものである。素材は新日本製鉄 (株)中央研究本部第二技術研究所萩原行人主任研究員 から供給していただいた。またデー夕整理に早稲田大学 大学院小出政俊氏の, 実験に早稻田大学理厂学部学生 (現：日産自動車(株)）川内理氏の協力をいただいた。 記してあつく御礼を申し上げます。

\section{文献}

1 ) H. Kotil.aink: ASTM-STP 700 (1980), p. 352 [ASTM, Philadelphia]

2 ) J. F. KNOTT: Fundamentals of Fracture Mechanics (1973) [Butterworth, London]

3 ) D. $J$. Al.exanier, $J$. $J$. Lewandowski, $W . J$. Sisak and A. W. Thompson: J. Mech. Phys. Solids, 34 (1986), p. 433

4 ) A. P. Grien and B. B. Huniv: J. Mech. Phys. Solids, 4 (1956), p. 128

5 ) J. W. Hutchinson: J. Mech. Phys. Solids, 16 (1968), p. 13

6 ) J. R. Rick and G. F. Rosengren: J. Mech. Phys. Solids, 16 (1968), p. 1

7 ) C. F. Shin and M. D. Grerman: Int. J. Fracture, 17 (1981), p. 27

8 ) F. A. McClinTock: Fracture, vol. 3, ed. by H. LikBowiT/ (1968) [Academic Press, N. Y.]

9 ) C. F. Sнгі: J. Mech. Phys. Solids, 29 (1981), p. 305

10) British Standard Methods for Crack Opening Diplacement Testing, BS 5762 (1979)

11）JIS ハンドブック鉄鐦（1983）[日本嫢格協会]

12）データシートシリーズ 4 「構造用鋼极の破壊䩲性.」 (1982), p. 80 [H本鉄铜協会]

13) $J . R$. Rick, $P . C$. PARIS and $J$. G. Mrkkl.e: ASTM-STP 536 (1973), p. 231 [ASTM, Philadelphia]

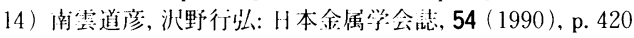

15) C. F. SHII: ASTM-STP 560 (1974), p. 187 [ASTM, Philadelphia]

16) $W . R$. Andrews and $C . F$. SHiH: ASTM-STP 668 (1979), p. 426 [ ASTM, Philadelphia]

17) $P$. C. Paris, $H$. TAdA, $A$. ZahoOr and $H$. ERnSt: ASTM-STP 668 (1979), p. 5 [ASTM, Philadelphia]

18) A. $R$. Rosenfinid, D. $K$. Shetty and $A . J$. Skidmore: Metall. Trans. A, 14 (1983), p. 1934

19) 田中泰彦, 渡辺十䬦, 少館忠雄: H本機械学会論文集 A, 54 (1988), p. 567 